\title{
MINIMUM DOSAGE OF THIOUREA, GIVEN TOGETHER WITH IODINE MEDICATION, NECESSARY FOR THE PRODUC- TION AND MAINTENANCE OF A REMISSION IN HYPERTHYROIDISM ${ }^{1}$
}

\author{
BY A. W. WINKLER, E. B. MAN, AND T. S. DANOWSKI \\ (From the Departments of Internal Medicine and Psychiatry, Yale University \\ School of Medicine)
}

(Received for publication November 27, 1946)

It has been shown that thiourea in amounts smaller than those recommended for thiouracil can produce a satisfactory remission in hyperthyroidism (1). The thyroid-depressant effect is enhanced if thiourea is used in combination with strong solution of iodine $(2,3,4)$. The administration of these two substances together results in a more rapid and more profound drop in the concentration of serum precipitable iodine than that observed with thiourea alone. Symptoms and signs of thyroid overactivity disappear along with or soon after the fall in serum precipitable iodine. Continued administration of thiourea, however, in the dosage initially used to produce a remission ( 280 to $210 \mathrm{mgm}$. daily) ultimately results in hypothyroidism in a number of patients. Ingestion of desiccated thyroid is followed by disappearance of the hypothyroidism and the serum precipitable iodine concentration returns to normal.

These facts suggest that the dosage initially employed was unnecessarily large. The present study arose from an attempt to avoid hypothyroidism by the use of the minimum effective dose of thiourea. To determine the magnitude of this, the effects of small doses of thiourea, 0.075 to 0.015 gram daily, together with iodine solution in inducing and maintaining a remission in hyperthyroidism have been studied. Results obtained with iodine medication alone, and those with amounts of thiourea greater than 0.075 gram are included for purposes of comparison.

\section{MATERIALS AND METHODS}

Data are presented on 4 groups of hyperthyroid subjects, some with diffuse goiter and some with adenomata. With but few exceptions the patients were not hospitalized. The diagnosis of thyroid overactivity was based primarily upon the presence of a concentration of serum

1 Aided by a grant from the Fluid Research Fund, Yale University School of Medicine. precipitable iodine of 8.0 gamma per cent or more $(5,6)$. This was usually but not invariably accompanied by an increase in the basal metabolic rate above plus 20 per cent. In all patients the clinical history and findings were compatible with the diagnosis of hyperthyroidism. No toxic reactions were observed in any of the patients during treatment with thiourea.

\section{RESULTS}

A. Production of a remission in hyperthyroidism. The effects of 2 treatment régimes on the course of active hyperthyroidism, measured by changes in the serum precipitable iodine, have been studied in 89 patients.

(1) Treatment with iodine and thiourea. Fifty hyperthyroid patients were treated with thiourea together with strong solution of iodine. Of these patients, 9 received 0.280 gram of thiourea daily in a single dose; 12 were treated with a total of 0.210 gram daily taken in 3 equal doses 8 hours apart; 17 other patients were started on either 0.070 gram in a single dose, or on 0.075 gram divided into 3 equal doses of $0.025 \mathrm{gram}$ each; the remaining 12 patients took 0.005 gram of thiourea 3 times daily for a total daily dose of 0.015 gram (Figure 1A, B, C, and D). Each patient in this group of 50 also received 5 drops of strong solution of iodine 3 times daily.

It is evident from the figure that equally satisfactory results were obtained with either 0.280 gram or 0.210 gram of thiourea daily in addition to iodine solution. At the end of 10 to 12 weeks of treatment or less, all but one patient in each of these 2 groups had developed concentrations of serum precipitable iodine of 8.0 gamma per cent or less (Figure 1A and B). The use of a smaller amount of thiourea, 0.07 gram daily, proved to be somewhat less effective. At the end of a similar period of treatment, 10 out of 13 patients had responded (Figure 1C). A daily intake of only 0.015 gram of thiourea, on the other hand, failed 

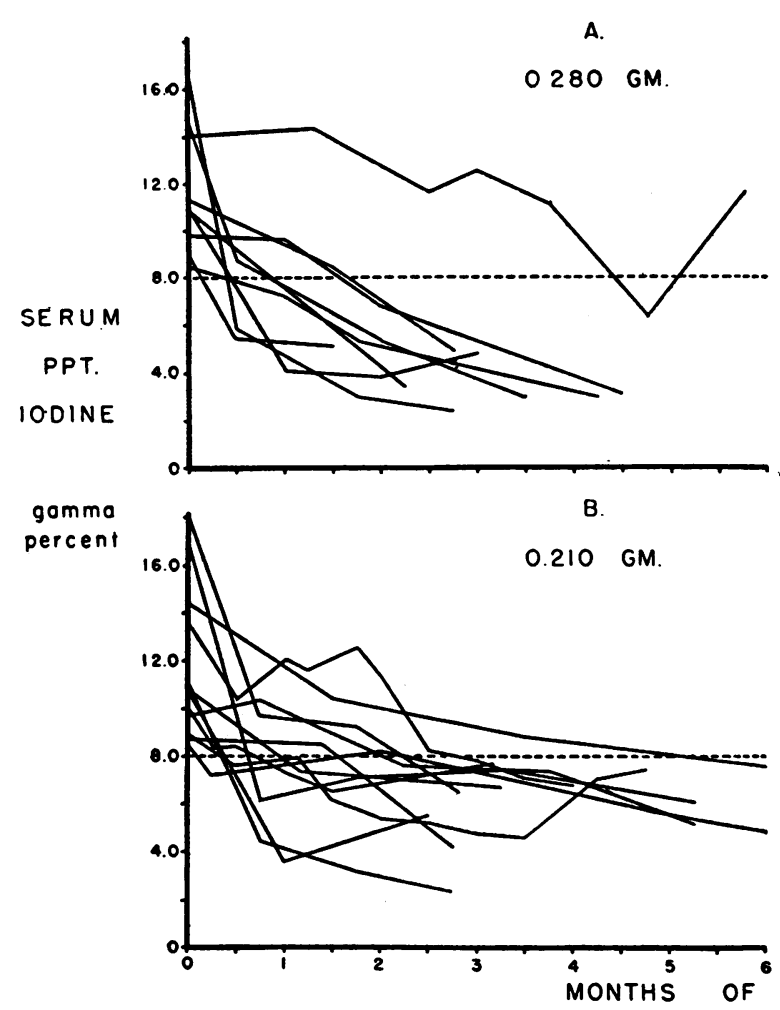
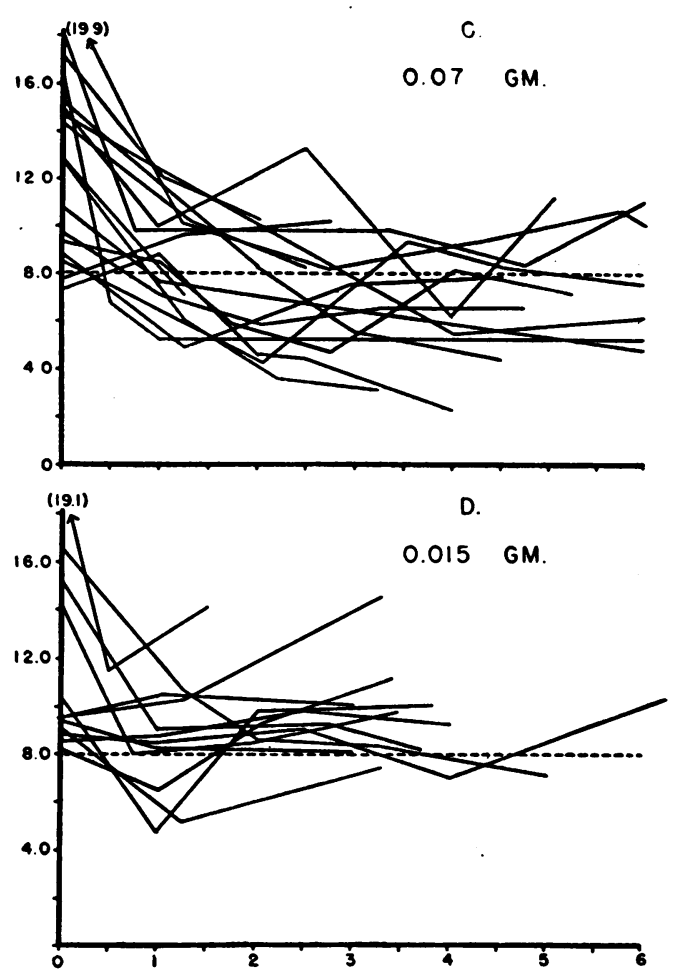

Fig. 1. Treatment of Hyperthyroidism with Iodine Solution Together with Thiourea

The return of the serum precipitable iodine to normal concentrations together with amelioration of the hyperthyroidism occurred almost as often in patients maintained on 0.07 gram of thiourea daily as it did in those on 0.280 or $0.210 \mathrm{gram}$. With doses as low as $0.015 \mathrm{gram}$ daily, however, no thiourea effect is apparent; the occasional response observed is to be attributed to the iodine solution.

with but 1 exception to bring and keep the hyperthyroidism under control (Figure 1D). Moreover, in contrast to the findings in the preceding 3 groups, hypothyroid levels of serum precipitable iodine (4.0 gamma per cent or lower) did not develop in any of these patients.

The response to these various doses of thiourea is also reflected in the values of the serum precipitable iodine at selected points during the course of treatment. The averaged values of the serum precipitable iodine, for example, were quite comparable prior to treatment in the 4 groups. They were $11.7 \pm 2.6,11.8 \pm 2.9,12.8 \pm 3.8$, and 11.7 \pm 3.6 gamma per cent in groups $\mathrm{A}, \mathrm{B}, \mathrm{C}$, and D respectively. After 10 to 12 weeks of treatment, the average value of the serum precipitable iodine in patients in group $A$ had declined to $5.7 \pm 2.9$ gamma per cent. The decrease was progressively less marked in groups $\mathrm{B}$ and $\mathrm{C}$ receiving smaller amounts of thiourea, since the average value in the former during the 10 - to 12 -week period was $6.5 \pm 2.0$ gamma per cent, and in the latter 6.9 \pm 2.3 . In group $\mathrm{D}$, however, the average level of precipitable iodine during a comparable period was $9.5 \pm 1.5$ gamma per cent. The serum precipitable iodine therefore declined significantly in groups $\mathrm{A}, \mathrm{B}$, and $\mathrm{C}$ but not in group $\mathrm{D}$. The differences in extent of decline among the first 3 groups are probably not significant.

(2) Treatment with iodine alone. Thirtynine patients were treated with strong solution of iodine alone, in a total daily dose of 15 drops. To simplify, graphic presentation results obtained with this therapy have been subdivided into 4 categories based upon changes in the concentration of the serum precipitable iodine (Figure 2A, B, C, and D). The serum precipitable iodine declined to and remained at euthyroid levels, 4.0 to 8.0 gamma per cent, in only 9 of the 39 patients (Figure 2A). In 6 other patients the serum precipitable iodine 

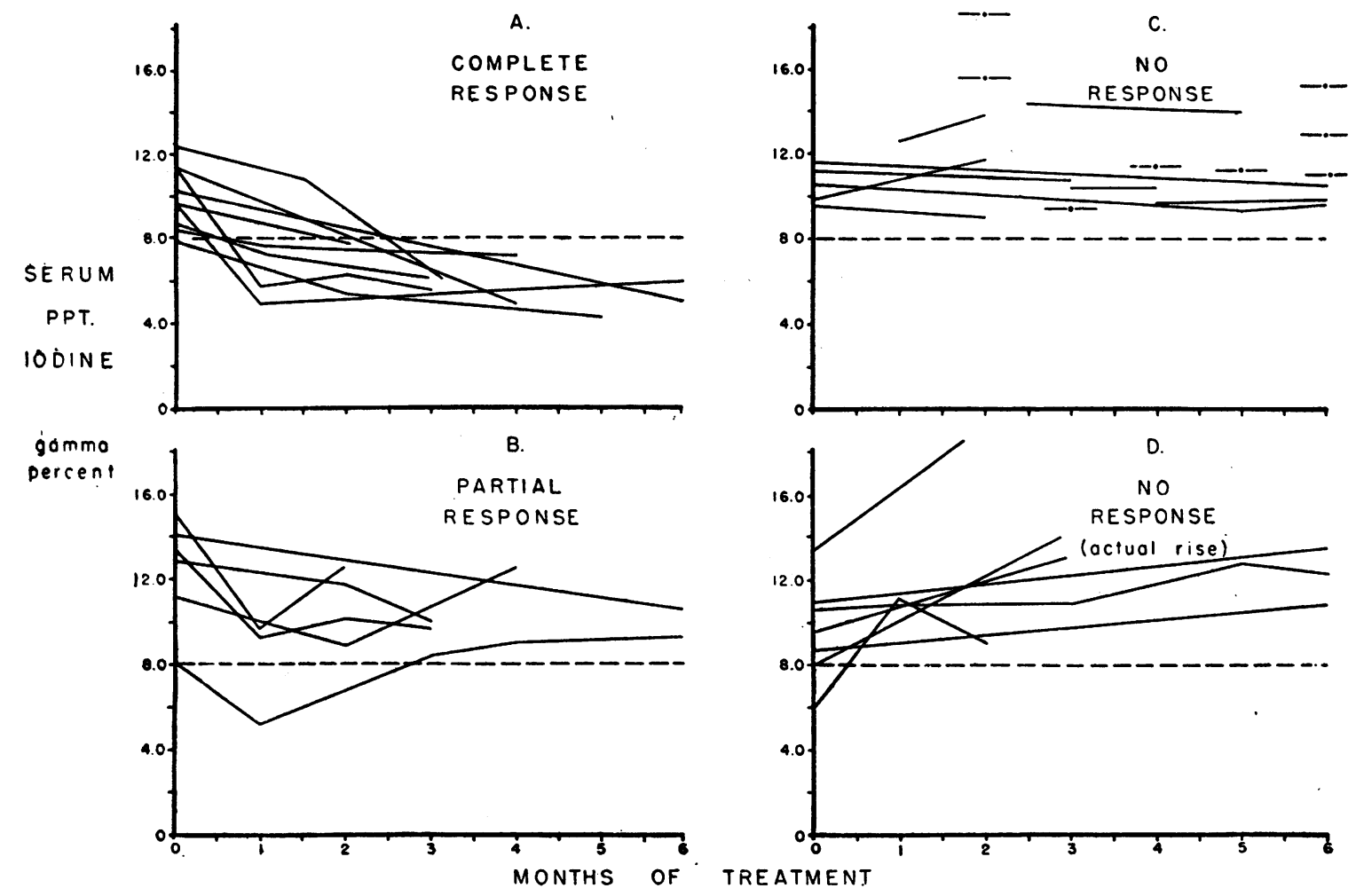

Fig. 2. Prolonged Treatment of Hyperthyroidism with Iodine Solution Only

Clinical improvement and euthyroid concentrations of serum precipitable iodine appeared and persisted in 9 of the 39 patients. In the remaining 30 patients the serum precipitable iodine, save for a temporary initial decrease in some instances, remained elevated and thyroid overactivity continued.

fell 2.0 gamma per cent or more, but in only 1 did the concentration become normal. This patient and' several others showed a subsequent rise to the pretreatment levels (Figure 2B). In the majority of patients, 17 in number, the serum precipitable iodine either failed to change at least 2.0 gamma per cent or was still distinctly elevated despite prolonged treatment with iodine solution (Figure 2C). In the 7 remaining patients, the serum precipitable iodine actually increased during iodine treatment (Figure 2D).

In those few patients in whom the concentration of serum precipitable iodine fell to normal levels the hyperthyroidism largely disappeared. Some of the others also showed a measure of clinical improvement. This did not always correlate in either magnitude or direction with the change in the serum precipitable iodine. In the majority of patients, however, the clinical symptoms and signs of thyroid overactivity continued unabated or actually increased during treatment with the iodine solution. None of the patients developed hypothyroid concentrations of iodine.

$B$. Maintenance on reduced amounts of thiourea and on iodine solution. The effectiveness of 0.07 , $0.05,0.035,0.025$, and $0.015-0.010$ gram doses of thiourea and 15 drops of iodine solution daily in maintaining the remission obtained by larger amounts of thiourea has been studied in 15 patients. Following the appearance of a stable euthyroid state the daily intake of the drug was reduced. In some of the patients the maintenance dose was decreased more than once. The strong solution of iodine, however, was continued throughout the entire treatment period in all 15 patients without alteration in dosage. Variations in the concentration of serum precipitable iodine following reduction in the dose of thiourea are presented in Table I together with other pertinent data.

The remission was maintained despite a reduction in the daily intake of thiourea to 0.07 gram 
in 11 patients in whom the initial response had been induced by $0.280,0.210$, or 0.140 gram. Further decrease in the maintenance dose of thiourea to $0.050,0.035$, or 0.025 gram resulted in a recurrence of hyperthyroidism in only 1 out of 11 trials (Patient E. B.). Attempts to control thyroid overactivity with 0.015 to 0.010 gram of thiourea daily failed, however, in 5 out of 8 patients.

In the 4 patients in whom the serum precipitable iodine decreased to 4.0 gamma per cent or lower, the level was raised to euthyroid values in $2(\mathrm{~Pa}$ tients F. W. and P. G.) and toward normal in the other 2 (Patients K. S. and S. L.) by reducing the daily intake of thiourea. Maintenance of a remission for prolonged periods of time is quite feasible, therefore, on 0.07 to 0.025 gram of thio-

TABLE I

Effects of reduction of dosage of thiourea following the initial remission of hyperthyroidism on thiourea and iodine solution

\begin{tabular}{|c|c|c|c|c|c|c|}
\hline Patient & $\begin{array}{c}\text { Dosage } \\
\text { of } \\
\text { thiourea }\end{array}$ & $\begin{array}{l}\text { Dura- } \\
\text { tion } \\
\text { from } \\
\text { start } \\
\text { of } \\
\text { thiourea }\end{array}$ & $\begin{array}{c}\text { Body } \\
\text { weight }\end{array}$ & $\begin{array}{c}\text { Pulse } \\
\text { rate }\end{array}$ & $\begin{array}{l}\text { Basal } \\
\text { meta- } \\
\text { bolic } \\
\text { rate* }\end{array}$ & $\begin{array}{c}\text { Serum } \\
\text { precipi- } \\
\text { table } \\
\text { iodine* }\end{array}$ \\
\hline E. B. & $\begin{array}{l}\text { Erams } \\
0.280 \\
0.070 \\
0.050\end{array}$ & $\begin{array}{c}\text { weeks } \\
0 \\
0-22 \\
22-28 \\
28-45\end{array}$ & $\begin{array}{c}\text { kila- } \\
\text { grams } \\
73.2 \\
76.1 \\
76.0 \\
75.0\end{array}$ & $\begin{array}{c}\text { per } \\
\text { minute } \\
100 \\
84 \\
84 \\
82\end{array}$ & per cent & $\begin{array}{c}\text { gamma } \\
\text { per cent } \\
8.3 \\
7.4 \\
8.0 \\
8.6\end{array}$ \\
\hline M. M. & $\begin{array}{l}0.140 \\
0.050\end{array}$ & $\begin{array}{c}0 \\
0-27 \\
27-55\end{array}$ & $\begin{array}{l}65.5 \\
75.6 \\
75.8\end{array}$ & $\begin{array}{l}70 \\
56 \\
60\end{array}$ & $\begin{array}{r}+39 \\
-9 \\
+2\end{array}$ & $\begin{array}{r}14.2 \\
4.5 \\
4.3\end{array}$ \\
\hline K. S. & $\begin{array}{l}0.210 \\
0.070 \\
0.035\end{array}$ & $\begin{array}{l}0 \\
0-10 \\
10-13 \\
13-21\end{array}$ & $\begin{array}{l}69.3 \\
69.7 \\
60.0\end{array}$ & $\begin{array}{l}72 \\
70 \\
64\end{array}$ & $\begin{array}{l}+36 \\
-19 \\
-26 \\
-28\end{array}$ & $\begin{array}{r}11.1 \\
2.4 \\
2.4 \\
3.2\end{array}$ \\
\hline S. L. & $\begin{array}{l}0.280 \\
0.070 \\
0.025\end{array}$ & $\begin{array}{l}0 \\
0-52 \\
52-69 \\
69-75\end{array}$ & $\begin{array}{l}49.9 \\
58.2 \\
62.5 \\
61.4\end{array}$ & $\begin{array}{l}84 \\
76 \\
76 \\
70\end{array}$ & $\begin{array}{r}+41 \\
-4 \\
-18 \\
-14\end{array}$ & $\begin{array}{l}9.8 \\
1.7 \\
2.9 \\
2.6\end{array}$ \\
\hline M. B. & $\begin{array}{l}0.210 \\
0.075 \\
0.025\end{array}$ & $\begin{array}{l}0 \\
0-21 \\
21-28 \\
28-45\end{array}$ & $\begin{array}{l}62.7 \\
60.9 \\
60.6 \\
60.7\end{array}$ & $\begin{array}{l}88 \\
52 \\
52 \\
56\end{array}$ & $\begin{array}{r}+18 \\
-4 \\
-11 \\
-6\end{array}$ & $\begin{array}{l}9.9 \\
5.4 \\
6.3 \\
7.5\end{array}$ \\
\hline E. C. & $\begin{array}{l}0.210 \\
0.070 \\
0.035 \\
0.025\end{array}$ & $\begin{array}{l}0 \\
0-11 \\
11-25 \\
25-39 \\
39-67\end{array}$ & $\begin{array}{l}57.6 \\
55.4 \\
58.6 \\
59.6 \\
54.4\end{array}$ & $\begin{array}{l}72 \\
60 \\
54 \\
62 \\
56\end{array}$ & $\begin{array}{r}+7 \\
+4 \\
-13 \\
-11 \\
-10\end{array}$ & $\begin{array}{l}8.7 \\
4.2 \\
4.4 \\
5.4 \\
6.1\end{array}$ \\
\hline J. H. & $\begin{array}{l}0.140 \\
0.070 \\
0.025\end{array}$ & $\begin{array}{l}0 \\
0-20 \\
20-28 \\
28-42\end{array}$ & $\begin{array}{l}58.0 \\
58.6 \\
58.6 \\
56.5\end{array}$ & $\begin{array}{r}114 \\
76 \\
80 \\
68\end{array}$ & $\begin{array}{r}+12 \\
+11 \\
+6\end{array}$ & $\begin{array}{r}14.1 \\
8.0 \\
7.3 \\
7.4\end{array}$ \\
\hline
\end{tabular}

TABLE I-Continued

\begin{tabular}{|c|c|c|c|c|c|c|}
\hline Patient & $\begin{array}{l}\text { Dosage } \\
\text { of } \\
\text { thiourea }\end{array}$ & $\begin{array}{c}\text { Dura- } \\
\text { tion } \\
\text { from } \\
\text { start } \\
\text { of } \\
\text { thiourea }\end{array}$ & $\begin{array}{c}\text { Body } \\
\text { weight }\end{array}$ & $\begin{array}{c}\text { Pulse } \\
\text { rate }\end{array}$ & $\begin{array}{l}\text { Basal } \\
\text { meta- } \\
\text { bolic } \\
\text { rate* }\end{array}$ & $\begin{array}{l}\text { Serum } \\
\text { precipi- } \\
\text { tabble } \\
\text { iodine* }\end{array}$ \\
\hline S. D. & $\begin{array}{l}\text { grams } \\
\\
0.140 \\
0.070 \\
0.015\end{array}$ & $\begin{array}{c}\text { weeks } \\
0 \\
0-11 \\
11-30 \\
30-38\end{array}$ & $\begin{array}{c}\text { kilo- } \\
\text { grams } \\
84.5 \\
\\
83.2 \\
84.0\end{array}$ & 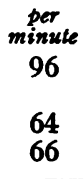 & $\begin{array}{c}\text { per cent } \\
+66 \\
+13\end{array}$ & $\begin{array}{c}\text { gamma } \\
\text { per cent } \\
13.3 \\
5.8 \\
7.0 \\
6.2\end{array}$ \\
\hline E. H. & $\begin{array}{l}0.075 \\
0.015\end{array}$ & $\begin{array}{l}0 \\
0-18 \\
18-30\end{array}$ & $\begin{array}{l}72.7 \\
75.4 \\
75.3\end{array}$ & $\begin{array}{l}84 \\
68 \\
66\end{array}$ & $\begin{array}{r}+40 \\
-1 \\
-1\end{array}$ & $\begin{array}{r}15.2 \\
4.4 \\
6.5\end{array}$ \\
\hline H. S. & $\begin{array}{l}0.075 \\
0.015\end{array}$ & $\begin{array}{l}0 \\
0-11 \\
11-31\end{array}$ & $\begin{array}{l}64.2 \\
67.2 \\
71.3\end{array}$ & $\begin{array}{l}80 \\
68 \\
68\end{array}$ & $\begin{array}{r}+14 \\
-5 \\
-9\end{array}$ & $\begin{array}{l}9.3 \\
4.9 \\
7.7\end{array}$ \\
\hline F. W. & $\begin{array}{l}0.210 \\
0.070 \\
0.015\end{array}$ & $\begin{array}{l}0 \\
0-24 \\
24-64 \\
64-76\end{array}$ & $\begin{array}{l}43.3 \\
45.0 \\
47.2 \\
47.0\end{array}$ & $\begin{array}{r}120 \\
82 \\
84 \\
88\end{array}$ & & $\begin{array}{r}12.2 \\
2.7 \\
5.9 \\
9.2\end{array}$ \\
\hline G. W. & $\begin{array}{l}0.210 \\
0.075 \\
0.015\end{array}$ & $\begin{array}{l}0 \\
0-31 \\
31-37 \\
37-43\end{array}$ & $\begin{array}{l}41.2 \\
49.7 \\
49.6 \\
46.4\end{array}$ & $\begin{array}{r}112 \\
76 \\
80 \\
100\end{array}$ & $\begin{array}{r}+48 \\
+6\end{array}$ & $\begin{array}{r}17.0 \\
6.1 \\
7.0 \\
11.6\end{array}$ \\
\hline P. G. & $\begin{array}{l}0.280 \\
0.070 \\
0.035 \\
0.013\end{array}$ & $\begin{array}{l}0 \\
0-32 \\
32-40 \\
40-63 \\
63-80\end{array}$ & $\begin{array}{l}60.8 \\
65.7 \\
67.9 \\
63.2 \\
65.4\end{array}$ & $\begin{array}{l}72 \\
60 \\
52 \\
48 \\
64\end{array}$ & $\begin{array}{r}+42 \\
-23 \\
-25 \\
+1 \\
+8\end{array}$ & $\begin{array}{r}22.2 \\
2.9 \\
3.9 \\
6.9 \\
13.1\end{array}$ \\
\hline M. A. & $\begin{array}{l}0.070 \\
0.035 \\
0.025 \\
0.013\end{array}$ & $\begin{array}{l}0 \\
0-19 \\
19-25 \\
25-37 \\
37-51\end{array}$ & $\begin{array}{l}59.2 \\
60.4 \\
61.4 \\
61.3 \\
60.5\end{array}$ & $\begin{array}{l}66 \\
68 \\
64 \\
60 \\
68\end{array}$ & $\begin{array}{r}-14 \\
-7 \\
-5 \\
-10 \\
-13\end{array}$ & $\begin{array}{l}9.7 \\
6.4 \\
7.4 \\
5.2 \\
9.4\end{array}$ \\
\hline I. A. & $\begin{array}{l}0.210 \\
0.075 \\
0.010\end{array}$ & $\begin{array}{l}0 \\
0-22 \\
22-28 \\
28-46\end{array}$ & $\begin{array}{l}57.4 \\
61.4 \\
60.5 \\
60.6\end{array}$ & $\begin{array}{l}78 \\
56 \\
58 \\
50\end{array}$ & $\begin{array}{l}+29 \\
-20 \\
-16 \\
-10\end{array}$ & $\begin{array}{r}12.8 \\
7.4 \\
6.3 \\
9.9\end{array}$ \\
\hline
\end{tabular}

* At end of period.

urea with only rare exacerbation of hyperthyroidism. Reductions to these amounts also prevent or correct myxedema. Amounts of thiourea as low as .015 gram, however, appear to be quite as ineffective in maintaining a remission as they were found to be in producing the initial response.

C. Effect of withdrawal of thiourea. In $10 \mathrm{pa-}$ tients, thiourea has been discontinued after administration in various amounts for 5 to 24 months, together with strong iodine solution. In 3 of these, the iodine solution was stopped along with the thiourea. In the remaining 7 , it was continued as the sole medication. All 10 patients in this group were free of hyperthyroid symptoms and 


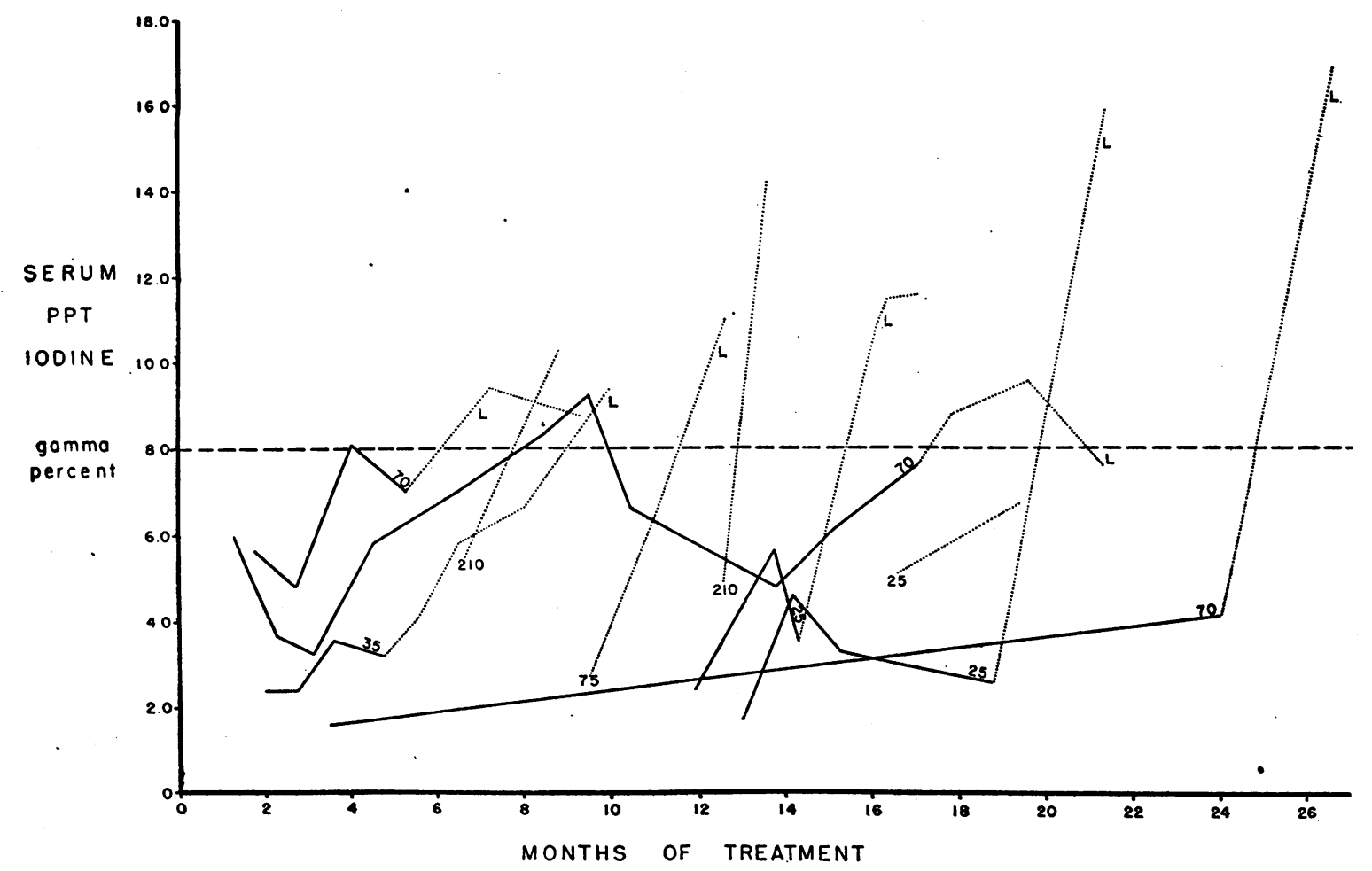

Fig. 3. EfFect of Withdrawal of Thiourea

In patients in remission on thiourea plus iodine, hyperthyroidism usually recurs if thiourea medication is omitted, even after months of treatment, and even if iodine medication (all lines marked " $L$ ") is continued. The numbers refer to the daily dosage of thiourea prior to withdrawal of this medication. Dotted lines indicate changes in serum precipitable iodine following cessation of thiourea therapy.

- had been repeatedly found to have euthyroid concentrations of serum precipitable iodine prior to the withdrawal of thiourea. The effect of this change in the therapeutic régime on the concentration of serum precipitable iodine is shown in Figure 3.

Hyperthyroidism recurred in 8 of the $10 \mathrm{pa}$ tients within 6 to 12 weeks after withdrawal of the drug. This high incidence of recurrence appears to be independent of whether the iodine solution was continued or discontinued at that time.

\section{DISCUSSION}

It is evident that in most patients it is not necessary to provide a daily intake of thiourea greater than 0.07 gram given with strong iodine solution in order to produce a rapid and complete remission in hyperthyroidism. Since a response to 0.015 gram of thiourea together with iodine solution is obtained in only a very small proportion of sub- jects, the minimum effective dose of thiourea, given in conjunction with iodine, must lie between 15 and $75 \mathrm{mgm}$. daily in most patients. Variations in individual response make more exact estimation difficult. Two advantages may be derived from the use of smaller doses of thiourea such as $70 \mathrm{mgm}$. rather than 210 or $280 \mathrm{mgm}$. First, it is possible that the number of toxic reactions may be minimized. Although in the studies reported in this paper no untoward reactions were encountered, drug fever developed in 2 patients in a previous series (2). Second, the smaller the dose employed, the less is the probability of the development of hypothyroidism. We have, therefore, adopted the following regular plan of treatment. Ambulatory patients are usually started on 70 $\mathrm{mgm}$. a day, along with strong solution of iodine, 5 drops 3 times a day. If they do not respond within 4 to 8 weeks, the dose is increased. Hospitalized patients with cardiac or other complica- 
tions, on the other hand, are from the start treated with the larger amounts in addition to iodine solution. Comparison between patients receiving the entire dose once a day and those in whom it was divided and spaced in 3 parts shows no significant difference in the response of the hyperthyroidism. Divided doses are preferable, however, in those patients subject to gastrointestinal reactions.

If $210 \mathrm{mgm}$. daily are employed initially, it is desirable to reduce the maintenance dose of thiourea to $70 \mathrm{mgm}$. daily or less once remission has occurred (Table I). In this way hypothyroidism and myxedema can usually be avoided entirely. The dose should not be reduced below $25 \mathrm{mgm}$. daily since $15 \mathrm{mgm}$. and smaller amounts are generally ineffective. The large proportion of recurrence which follows the cessation of thiourea therapy (Figure 3 ) effectually disposes of the possibility that the hyperthyroidism has been cured.

In a previous paper (2), the additive effects of iodine and thiourea in the larger doses, 280 or 210 mgm. daily, were demonstrated. Too few observations on the effects of $70 \mathrm{mgm}$. daily doses of thiourea without iodine are as yet available to establish that this same additive effect is present at these low levels of dosage. The possibility, on the other hand, that the beneficial effects of this combined form of therapy are to be ascribed chiefly to the iodine solution given can be easily discarded. From Figure 2 it is evident that iodine solution by itself only rarely produces a sustained remission in hyperthyroidism, and from Figure 3 it is clear that iodine alone cannot sustain a remission produced by thiourea. These results confirm the general impression that continued treatment of hyperthyroidism with iodine medication alone is generally unsatisfactory.

The physiological effect of these small amounts of thiourea point to a particular sensitivity of the thyroid gland to this drug, since, at least in the normal dog, there is no tendency for the thyroid gland to destroy or concentrate thiourea in measurable amounts (7). Thiourea does not accumulate in the body to any extent and is distributed through most of the body fluids in about the same concentration as that found in serum water (7). The concentration of thiourea in serum after a daily dose of $25 \mathrm{mgm}$. is too low to measure by present analytical methods, but the general range may be estimated from the volume of distribution of thiourea (about 0.8 times the body weight) and its renal clearance (50 to $60 \mathrm{ml}$. per minute) (8). This calculation indicates that the concentration ranges from 5 to 50 gamma per cent of thiourea in body fluids including, presumably, the available water of the thyroid gland. These are to be compared with concentrations of inorganic iodine in the water of the thyroid gland of the magnitude of $10 \mathrm{mgm}$. per cent, or 10,000 gamma per cent (9). It seems improbable that relatively few molecules of thiourea can combine with and render unavailable, as has been suggested $(10,11)$, this great excess of inorganic iodine. The thiourea effect appears to be mediated, rather, through a block at a crucial link in the chain of reactions through which all of the iodide which is converted to organic iodine must pass. The studies reported in this paper indicate that this block in the conversion of inorganic iodine to diiodotyrosine and thyroxine can be produced by almost infinitesimal traces of thiourea.

The fact that iodine medication does not interfere with the action of thiourea, even when the latter is present in relatively trifling amounts, and the fact that their actions are additive, prove that these substances act at quite different points. There is good evidence that iodine has two separate actions on the hyperthyroid gland; the first inhibits the effect of thyrotropic hormone, the second favors the accumulation of iodine within the gland, as a result of an excess of inorganic iodine (9). Thiouracil and related drugs interfere with neither action (12 to 15 ). Since they certainly prevent the synthesis of thyroxine and diodotyrosine from inorganic iodine (13), it is reasonable to suggest that they may act by poisoning the enzyme system responsible for this synthesis. The lack of interference in the action of thiourea by iodine in large excess is most readily explained in this way. The experiments of Astwood (10) in which he demonstrated a greater goitrogenic potency of thiouracil in animals maintained on a low iodine diet than in those on a high iodine diet do not prove that there is a direct interference between iodine and thiouracil. The high iodine diet more probably acts by inhibiting thyrotropic hormone action and so delaying the development of goiter. 


\section{SUMMARY AND CONCLUSIONS}

1. Doses of thiourea as small as 0.07 gram daily, in conjunction with iodine solution, produce a remission in hyperthyroidism with considerable regularity.

2. The remission in hyperthyroidism can usually be maintained by the use of 0.05 to 0.025 gram of thiourea daily in addition to iodine solution.

3. A daily intake of 0.015 gram of thiourea together with iodine solution does not induce a remission, or maintain it, following the use of larger amounts.

4. Withdrawal of thiourea, even when the maintenance dose is as low as 0.025 gram, is frequently followed by exacerbation of a previously controlled hyperthyroidism.

5. Control of hyperthyroidism with iodine solution alone is only rarely possible, with or without previous thiourea treatment.

6. Prolonged, and perhaps indefinite, maintenance on thiourea and iodine is necessary to prevent recrudescence of hyperthyroidism.

\section{BIBLIOGRAPHY}

1. Danowski, T. S., Man, E. B., and Winkler, A. W., Treatment of hyperthyroidism with a combination of iodine, thiourea in small doses, and desiccated thyroid. Am. J. M. Sc., 1945, $202,777$.

2. Danowski, T. S., Man, E. B., and Winkler, A. W., Additive effects of iodine and thiourea in the treatment of hyperthyroidism. J. Clin. Invest., 1946, 25, 597.

3. Danowski, T. S., Man, E. B., and Winkler, A. W., Metabolism of thiourea: additive effects of iodine and thiourea in the treatment of hyperthyroidism. J. Clin. Invest., 1946, 25, 921.

4. Danowski, T. S., and Winkler, A. W., The use of thiourea in the control of hyperthyroidism. Conn. State M. J., 1947, 11, 105.
5. Riggs, D. S., and Man, E. B., A permanganate acid ashing micromethod for iodine determinations. I. Values in blood of normal subjects. J. Biol. Chem., 1940, 134, 193.

6. Winkler, A. W., Riggs, D. S., Thompson, K. W., and Man, E. B., Serum iodine in hyperthyroidism with particular reference to the effects of subtotal thyroidectomy. J. Clin. Invest., 1946, 25, 404.

7. Danowski, T. S., Unpublished data.

8. Nicholes, H. J., and Herrin, R. C., The tubular reabsorption of urea, thiourea and derivatives of thiourea in the dog kidney. Am. J. Physiol., 1941, 135,113 .

9. Rawson, R. W., Moore, F. D., Peacock, W., Means, J. H., Cope, O., and Riddell, C. B., Effect of iodine on the thyroid gland in Graves' disease when given in conjunction with thiouracil-a two action theory of iodine. J. Clin. Invest., 1945, 24, 869.

10. Astwood, E. B., Chemotherapy of hyperthyroidism. Harvey Lectures, 1944-45.

11. Formijne, P., Probable mode of action of thiourea and thiouracil on the thyroid function. Proc. Netherlands Acad. Sci., 1946, 49, 484.

12. Larson, R. A., Keating, F. R., Jr., Peacock, W., and Rawson, R. W., A comparison of the effect of thiouracil and of injected thyrotropic hormone on the collection of radioactive iodine and the anatomic changes induced in the thyroid of the chick. Endocrinol., 1945, 36, 149.

13. Franklin, A. L., Chaikoff, I. L., and Lerner, S. R., The influence of goitrogenic substances on the conversion in vitro of inorganic iodide to thyroxine and diiodotyrosine by thyroid tissue with radioactive iodine as indicator. J. Biol. Chem., 1944, 153, 151.

14. Franklin, A. L., Lerner, S. R., and Chaikoff, I. L., The effect of thiouracil on the formation of thyroxine and diiodotyrosine by the thyroid gland of the rat with radioactive iodine as indicator. Endocrinol., 1944, 34, 265.

15. Rawson, R. W., Tannheimer, J. F., and Peacock, W. C., The uptake of radioactive iodine by the thyroids of rats made goiterous by potassium thiocyanate and by thiouracil. Endocrinol., 1944, 34, 245. 